\title{
KEBIJAKAN PEMBANGUNAN PARIWISATA YANG BERWAWASAN LINGKUNGAN DI KABUPATEN GUNUNGKIDUL
}

\author{
Sunawan \\ Magister Ilmu Hukum, Program Pascasarjana, Universitas Muhammadiyah Yogyakarta \\ Jl. Brawijaya Kasihan Bantul Yogyakarta 55183 \\ sunawan.sh@gmail.com
}

\begin{abstract}
Gunungkidul Regency is blessed with Allah SWT natural resources in the form of very beautiful tourist attractions. In 2017, there were 3,236,931. Foreign tourists (foreign countries) in 2017 amounted to 21,082. The tourism business is indeed lucrative because it can increase the community economy. But on the other hand natural preservation must still be maintained..This study aims to examine how the policies of the Gunungkidul Regency Government in the development of environmentally friendly tourism. This research is a doctrinal law research with a statutory approach and a concept approach. Data collection techniques using literature study and interview techniques. The results showed that there are several policies of the Gunungkidul Regency Government in building tourism are Installing Environmental Signboards in tourist sites, Placing cleaning staff in tourist objects, Ecotourism or Ecotorism, Preparation of AMDAL in Tourism Areas and Management of Capacity and Carrying Capacity Attraction Tour. The conclusion of the research is that Tourism Development in Gunungkidul Regency has led to environmental preservation but there are still obstacles in its implementation due to lack of coordination between institutions. and stakeholders.
\end{abstract}

Keywords: Environment, Government Policy, Tourism.

\begin{abstract}
Abstrak
Kabupaten Gunungkidul dikarunia Allah SWT sumber daya alam berupa tempat-tempat wisata yang sangat indah. Pada Tahun 2017 sejumlah 3.236.931. Wisatawan asing (manca negara) pada Tahun 2017 sejumlah 21.082. Bisnis pariwisata memang menggiurkan karena dapat meningkat perekoniam masyarakat. Namun disisi lain kelestaian alam tetap harus dijaga. Penelitian ini bertujuan untuk mengkaji bagaimana kebijakan Pemerintah Kabupaten Gunungkidul dalam pembangunan pariwisata yang berwawawasan lingkungan. Penelitian ini adalah penelitian hukum doktrinal dengan pendekatan perundang-undangan dan pendekatan konsep. Teknik pengumpulan data menggunakan teknik studi kepustakaan dan wawancara. Hasil penelitian menunjukkan bahwa ada beberapa kebijakan Pemerintah Kabupaten Gunungkidul dalam membangun pariwasata adalahMemasang Papan Rambu Lingkungan Hidup di tempat-tempat wisata,Menempatkan petugas kebersihan di obyek-obyek wisata, Ekowisata atau Ekotorisme, Penyusunan AMDAL Kawasan Pariwisata dan Pengelolaan Daya Tampung dan Daya Dukung Daya Tarik Wisata.

Kesimpulan penelitian adalah Pembangunan Pariwisata di Kabupaten Gunungkidul sudah mengarah pada pelestarian lingkungan tetapi masih ada kendala dalam implementasinya karena kurangnya koordinasi antar lembaga. dan stakeholder.
\end{abstract}

Kata Kunci: Kebijakan Pemerintah, Pariwisata, lingkungan hidup. 


\section{PENDAHULUAN}

Salah satu tujuan dibentuknya Negara Kesatuan Republik Indonesia sebagaimana diamanatkan dalam Pembukaan Undang-Undang Dasar Republik Indonesia adalah untuk memajukan kesejahteraan umum. Negara mempunyai kewajiban untuk mensejahterakan warga masyarakatnya melalui berbagai program pembangunan dengan memanfaatkan sumber daya alam yang ada di Indonesia. Berdasarkan Undang-Undang Dasar Negara Republik Indonesia Tahun 1945 Pasal 33 ayat (3) bahwa bumi dan air dan kekayaan alam yang terkandung didalamnya dikuasai oleh negara dan dipergunakan untuk sebesar-besarnya kemakmuran rakyat. ${ }^{1}$ Salah satu upaya pemerintah untuk mewujudkan tujuan negara yaitu mensejahterakan warga masyarakatnya dengan memanfaatkan potensi sumber daya alam yang ada di Indonesia adalah dengan melakukan pembangunan pariwisata.

Pariwisata sebagaimana dimaksud pada Undang-Undang Republik Indonesia Nomor 10 Tahun 2009 tentang Kepariwisataan adalah Pariwisata merupakan berbagai macam kegiatan wisata dan didukung berbagai fasilitas serta layanan yangdisediakan oleh masyarakat, pengusaha, Pemerintah,dan Pemerintah Daerah. ${ }^{2}$ Sedangkan wisata adalah kegiatan perjalanan yang dilakukanoleh seseorang atau sekelompok orang dengan mengunjungi tempat tertentu untuk tujuan rekreasi, pengembangan pribadi, atau mempelajari keunikandaya tarik wisata yang dikunjungi dalam jangkawaktu sementara. ${ }^{3}$

Perkembangan pembangunan pariwisata di berbagai daerah di Indonesia yang cukup bagus selama dasa warsa terakhir ternyata tidak lepas dari efek negatif yang ditimbulkannnya. Disamping kemampuannya dalam memberikan sumbangan yang berarti dari segi ekonomi, pembangunan pariwisata yang hanya berorientasi pada segi ekonomi dan mengabaikan segi non ekonomi berupa lingkungan hidup dan budaya masyarakat telah mengakibatkan terjadinya banyak kerusakan terutama kerusakan berupa pencemaran lingkungan hidup dan juga terjadinya pergeseran budaya masyarakat, adanya penggusuran, semakin maraknya prostitusi dan terpinggirkannya masyarakat disekitar obyek wisata.

Hal tersebut tentunya sangat bertentangan dengan tujuan digalakkannya pembangunan pariwisata, sebagaimana diamanatkan dalam Undang-Undang Republik Indonesia Nomor 10 Tahun 2009 tentang Kepariwisataan, bahwa tujuan Kepariwisataan adalah untuk:

a. meningkatkan pertumbuhan ekonomi;

b. meningkatkan kesejahteraan rakyat;

c. menghapus kemiskinan;

d. mengatasi pengangguran;

e. melestarikan alam, lingkungan, dan sumber daya;

f. memajukan kebudayaan;

g. mengangkat citra bangsa;

h. memupuk rasa cinta tanah air;

i. memperkukuh jati diri dan kesatuan bangsa; dan

j. mempererat persahabatan antarbangsa. ${ }^{4}$

\footnotetext{
${ }^{1}$ R.I., Undang-Undang Dasar 1945, Bab XIV, Pasal 33, ayat 3

2 R.I., Undang-Undang Nomor 10 Tahun 2009 tentang Kepariwisataan, Bab I, Pasal 1, ayat 3

${ }^{3}$ Ibid, ayat 1

${ }^{4}$ R.I., Undang-Undang Nomor 10 Tahun 2009, tentang “Kepariwisataan”, op. cit. Bab II, Pasal 4
} 
Kegiatan atau aktivitas pariwisata pada perkembangannya telah menjadi industri pariwisata dan merupakan salah satu sektor yang dapat memberikan keuntungan secara ekonomi. Di negara sedang berkembang seperti Indonesia, sektor pariwisata dijadikan sebagai salah satu sumber devisa negara, lebih-lebih adanya pandangan bahwa pariwisata merupakan eksport yang tidak kentara (Invisibleexport) yang tidak mencemari lingkungan (smokeless industries), dan industri yang tidak akan pernah berakhir (never ending industries) telah mendorong para pengambil keputusan guna lebih memberikan penekanan pada aspek keuntungan ekonomi daripada konsekuensi kelestarian lingkungan. Pertimbangan terhadap aspek kelestarian sering dikalahkan dengan alasan ekonomi. Adanya paradigma demikian menyebabkan kecenderungan pengembangan pariwisata dilakukan dalam skala besar- besaran (massive) yang berdampak adanya degradasi lingkungan, baik fisik biotis maupun lingkungan sosial budaya. ${ }^{5}$

Pariwisata ternyata tidak selalu menimbulkan dampak positif seperti: penghasil devisa, membuka lapangan kerja dan pertumbuhan ekonomi; akan tetapi secara bersamaan juga menimbulkan berbagai dampak negatif seperti nilai-nilai sosial budaya maupun pencemaran lingkungan fisik dan biotis. Isu dampak negatif pariwisata ini mengakibatkan perubahan paradigma pembangunan pariwisata, dari model pariwisata massal (mass tourism) atau pariwisata konvensional ke model pariwisata alternatif (alternativetourism). ${ }^{6}$

Menurut Koslowskidan Travis, Pariwisata alternatif merupakan suatu bentuk kegiatan kepariwisataan yang tidak merusak lingkungan, berpihak pada ekologis dan menghindari dampak negatif dari pembangunan pariwisata berskala besar yang dijalankan pada suatu area yang tidak terlalu cepat pembangunannya. Merujuk dari pengertian menurut ahli tersebut, maka pariwisata alternatif adalah pariwisata yang muncul guna meminimalisir dampak negatif dari perkembangan pariwisata masal yang terjadi hingga saat ini. Dampak negatif dari pariwisata masal atau pariwisata berskala besar adalah ancaman terhadap kelestarian budaya dimana budaya lebih dikomersialisasikan dibandingkan dijaga keaslian dan kelestariannya. Selain itu dampak negatif yang dapat berbahaya adalah perusakan sumber daya alam dimana sumber daya alam habis dieksploitasi besar-besaran. Selain itu pariwisata alternatif menurut Saglio dan Gonslves adalah kegiatan kepariwisataan yang memiliki gagasan yang mengandung arti sebagai suatu pembangunan yang berskala kecil atau juga sebagai suatu kegiatan kepariwisataan yang disuguhkan kepada wisatawan, dimana segala aktivitasnya turut melibatkan masyarakat. Jadi, bisa disimpulkan pembangunan pariwisata yang baik dan mendukung kelestarian sumber daya baik alam, budaya dan manusia adalah pariwisata alternatif. ${ }^{7}$

Dalam Konferensi Tingkat Tinggi Bumi di Rio de Janeiro tahun 1992, masalah dampak negatif pariwisata terhadap lingkungan secara khusus tidak disinggung.Akan tetapi, dengan semakin meningkatnya kesadaran masyarakat dunia terhadap masalah pencemaran dan kelestarian lingkungan maka paradigma pembangunan pariwisata mengalami pergeseran, dari pariwisata alternatif ke ekowisata (ecotourism). ${ }^{8}$

\footnotetext{
${ }^{5}$ Timang Setyorini, SH, 2004,"Kebijakan Pariwisata Dalam Rangka Meningkatkan Pendapatan Ekonomi Masyarakat Kabupaten Semarang" (Tesis Pascasarjana tidak diterbitkan, Program Magister Ilmu Hukum Universitas Diponegoro Semarang), hlm 2

${ }^{6}$ Ibid.

${ }^{7}$ https://borneotourismwatch.wordpress.com/2009/09/09/pariwisata-alternatif-apa-itu, diunduh tanggal 30 Oktober 2018, pukul 09.45 WIB.

${ }^{8}$ Ibid, hlm 3
} 
Pembangunan pariwisata harus memperhatikan aspek kelestarian lingkungan hidup karena menyangkut kebutuhan generasi yang akan datang. Mewarisi alam dan lingkungan hidup yang lestari kepada anak cucu dan generasi yang akan datang adalah kewajiban kita sebagai bangsa yang beradap sebagaimana dimaksud dalam Undang-Undang Republik Indonesia Nomor 32 Tahun 2009 tentang Perlindungan dan Pengelolaan Lingkungan Hidup Pasal 3 huruf f dan huruf g bahwa Perlindungan dan pengelolaan lingkungan hidup bertujuan untuk menjamin terpenuhinya keadilan generasi masa kini dan generasi masa depan dan menjamin pemenuhan dan perlindungan hak atas lingkungan hidup sebagai bagian dari hak asasi manusia. ${ }^{9}$

Pemerintah mempunyai peran sangat strategis dalam pembangunan pariwisata di daerah. Berdasarkan Undang-Undang Republik Indonesia Nomor 23 Tahun 2014 tentang Pemerintah Daerah Pasal 12 ayat (3) bahwa pariwisata menjadi urusan pemerintahan pilihan. Disebutkan dalam Pasal 9 ayat (1) bahwa Urusan Pemerintahan terdiri atasurusan pemerintahan absolut, urusan pemerintahan konkuren, dan urusan pemerintahan umum.Pada ayat (3) menyebutkan bahwa Urusan pemerintahan konkuren sebagaimana dimaksud pada ayat (1) adalah Urusan Pemerintahan yang dibagi antara Pemerintah Pusat dan Daerah provinsi dan Daerah kabupaten/ kota. Sedangkan pada ayat (4) menyebutkan bahwa Urusan pemerintahan konkuren yang diserahkan ke Daerah menjadi dasar pelaksanaan Otonomi Daerah. Ketentuan-ketentuan inilah yang dijadikan dasar Pemerintah Daerah dalam mengelola dan mengembangkan potensi alam menjadi obyek wisata.

Kabupaten Gunungkidul mempunyai beragam potensi perekonomian mulai dari pertanian, perikanan dan peternakan, hutan, flora dan fauna, industri, tambang serta potensi pariwisata. ${ }^{10}$ Potensi wisata atau destinasi banyak dijumpai di Kabupaten Gunungkidul yaitu :

a. Destinasi Pantai yang sangat luas dan tersebar disepanjang wilayah selatan Kabupaten Gunungkidul antara lain : Pantai Kukup, Pantai Drini, Pantai Sepanjang, Pantai Indrayanti, Pantai Timang, Pantai Jogan, Pantai Sundak, PantaiWediombo, Pantai Siung, Pantai Krakal, Pantai Baron, Pantai Ngobaran, Pantai Ngrenehan, Pantai Nguyahan, Pantai Ngandong, Pantai Pok Tunggal dan Pantai Nglambor.

b. Destinasi Goa yang berada di Kabupaten Gunungkidul antara lain : Goa Pindul yang berlokasi di wilayah Kecamatan Karangmojo, Goa Jomblang yang berlokasi diwilayah Kecamatan Semanu, Goa Cokro yang berlokasi di wilayah Kecamatan Ponjong, Kali Suci yang berlokasi di wilayah Kecamantan Semanu, dan Goa Rancang Kencono yang berlokasi di wilayah Kecamatan Playen.

c. Destinasi Gunung yang berada di Kabupaten Gunungkidul antara lain : Gunung Gambar yang berlokasi di wilayah Desa Kampung Kecamatan Ngawen, Gunung Ireng yang berlokasi di wilayah Desa Pengkok Kecamatan Patuk, Gunung Gentong yang berlokasi di wilayah Desa Ngalang Kecamatan Gedangsari dan Nglanggeran (Gunung Api Purba) yang berlokasi di wilayah Desa Nglanggeran Kecamatan Patuk. ${ }^{11}$

\footnotetext{
${ }_{9}^{9}$ R.I., Undang-UndangNomor 32 Tahun 2009 tentang Perlindungan dan Pengelolaan Lingkungan Hidup,Bab II, Pasal 3 huruf f dan huruf g

${ }^{10} \mathrm{http}$ //gunungkidulkab.go.id/D-947db8881fd2f1e605a1fe29a8b6aa6c-NR-100-0.html, diunduh pada tanggal 22 Juni 2018, pukul 08.30.

${ }^{11} \mathrm{http} / / /$ wisata.gunungkidulkab.go.id/, diunduh pada tanggal 22 Juni 2018, pukul 09.30.
} 
Pemerintah Kabupaten Gunungkidul perlu mengambil kebijakan pembangunan pariwisata yang berwawasan lingkungan agar keindahan alam tetap bisa dinikmati oleh anak cucu kita. Menghentikan bentuk-bentuk kerusakan alam dikawasan wisata.

Berdasarkan uraian tersebut di atas rumusan masalah yang diajukan adalah, Bagaimana kerusakan lingkungan di kawasan wisata di Kabupaten Gunungkidul. Bagaimanakah upaya Pemerintah Kabupaten Gunungkiduldalam mengatasi kerusakan lingkungan di kawasan wisata sehingga terwujud pembangunan pariwisata yang berwawasan lingkungan.

\section{TELAAH KONSEP}

\section{Kebijakan Pemerintah}

Pembangunan Daerah sebagai bagian integral dari pembangunan nasional tidak bisa di lepaskan dari prinsip otonomi daerah. Sebagai Daerah Otonom, Daerah mempunyai kewenangan dan tanggung jawab menyelenggarakan kepentingan masyarakat berdasarkan prinsip keterbukaan partisipasi masyarakat dan pertanggung jawaban masyarakat. ${ }^{12}$

Istilah kebijakan adalah disepadankan dengan kata policy kata yang dibedakan dengan kebijaksanaan (wisdam) maupun kebijakan (Virtues). Istilah kebijakan ini penggunaannya sering dipertukarkan seperti istilah-istilah lain seperti tujuan (goals), program keputusan undang undang, ketentuan-ketentuan, standar,proposal dan Grand design. Menurut Carl Fredrich Kebijakan adalah suatu tindakan yang mengarah pada tujuan yang diusulkan oleh seseorang, kelompok atau pemerintah dalam suatu lingkungan tertentu sehubungan dengan adanya hambatan-hambatan tertentu seraya mencari peluang-peluang untuk mencapai tujuan atau mewujudkan saran yang di inginkan.

\section{Makna Kedudukan Hukum dan Kebijakan Publik}

Pada hakikatnya, ketika ditelisik lebih mendalam istilah Rechtsstaat dan Rule of law memiliki makna yang berbeda antara. Sebagaimana diidentifikasikan oleh Roscoe Pound ${ }^{13}$, bahwa Rechtsstaat memiliki karakter administratif sedangkan Rule of law berkarakter yudisial. Dalam kaitannya dengan negara hukum, kedaulatan rakyat merupakan unsur material negara hukum, di samping masalah kesejahteraan rakyat dan kebijakan pelayanan yang pro publik. Artinya hukum selalu menjadi pengendali dinamika sosial yang ada dan terjadi di masyarakat dalam suatu negara.

\section{Pembangunan}

Arti Pembangunan menurut Prof. Denis Goulet, "minimal ada tiga komponen dasar atau tata nilai yang seharusnya menjadi dasar konsepsi dan panduan praktis agar benar-benar bisa memahami arti pembangunan. Tiga tata nilai yang dimaksud itu yakni, pertama yang berkaitan

\footnotetext{
${ }^{12}$ Darwawan Boamona dan Ulung Pribadi, "Pelaksanaan Kebijakan Pembangunan Kawasan Khusus Pariwisata di Kabupaten Kepulauan Sula Provinsi Maluku Utara Tahun 2014", Jurnal Ilmu Pemerintahan dan Kebijakan Publik. Vol. 2 No. 3, Oktober 2015.

${ }^{13}$ Roscoe Pound, 1957. The development of Constitutional Guarantees of Liberty, Yale University Press. New Heaven London. Hlm. 7. Lebih jauh perbedaan tersebut dapat di lihat Moh. Mahfud MD, 2006. Membangun Politik hukum, Menegakkan Konstitusi. Pustaka LP3ES Jakarta. Hlm. 25... “Bahwa perbedaan konsepsi tersebut sebenarnya lebih terletak pada operasionalisasi atas substansi yang sama yakni perlindungan atas hak-hak asasi manusia, sebab secara substantif kedua konsepsi negara hukum tersebut sama-sama bertujuan untuk memberikan perlindungan atas hak asasi dan hak konstirusional warga negara"
} 
dengan nafkah hidup. Dalam hal ini bahwa setiap orang mempunyai kebutuhan hidup yang pokok seperti pangan, papan, kesehatan, dan perlindungan. Kedua, harga diri menjadi orang. Dalam hal ini dinilai bahwa kehidupan yang baik adalah sikap yang bisa menghargai diri sendiri. Sikap percaya dan hormat terhadap diri sendiri tidak digunakan sebagai alat dari tujuan-tujuannya. Ketiga, sasaran pembangunan. Singkatnya pembangunan merupakan suatu kenyataan fisik dan suatu keadaan jiwa yang diupayakan cara-caranya oleh masyarakat melalui kombinasi berbagai proses sosial, ekonomi, dan kelembagaan untuk mencapai kehidupan yang lebih baik."14

\section{Pariwisata}

Pariwisata adalah keseluruhan fenomena (gejala) dan hubungan yang ditimbulkan oleh perjalanan dan persinggahan manusia di luar tempat tinggalnya, dengan maksud bukan untuk tinggal menetap di tempat yang disinggahinya dan tidak berkaitan dengan pekerjaan yang menghasilkan upah. ${ }^{15}$

Guyer-Freuler dalam Nyoman S. Pendit (2002:34) merumuskan pariwisata sebagai berikut; Pariwisata dalam arti modern adalah merupakan gejala zaman sekarang yang di dasarkan atas kebutuhan akan kesehatan dan pergantian hawa, penilayan yand sadar dan menempuh terhadap keindahan alam kesenangan dan kenikmatan alam semesta, dan pada khususnya di sebabkan oleh bertambahnya pergulatan berbagai bangsa dan kelas dalam masyarakat sebagai hasil perkembangan perniagaan, industri dan perdagangan serta penyempurnaan alat alat pengangkutan. ${ }^{16}$

\section{Pembangunan Berwawasan Lingkungan}

Emil Salim mendefinisikan pembangunan berwawasan lingkungan merupakan upaya sadar dan berencana dalam menggunakan dan mengelola sumber daya alam secara bijaksana dalam pembangunan yang berkesinambungan untuk meningkatkan kualitas hidup. Emil Salim berpendapat bahwa pembangunan berkelanjutan bertujuan untuk meningkatkan kesejahteraan masyarakat, untuk memenuhi kebutuhan dan aspirasi manusia. Secara umum pembangunan yang berkelanjutan pada hekekatnya dilaksanakan dalam rangka menjamin keberlangsugan hidup generasi masa akan datang melalui pemerataan pembangunan.

Secara garis besar, pembangunan berkelanjutan yang berwawasan lingkungan merupakan pembangunan yang tidak mengabaikan kelestarian lingkungan, menjaga keharmonisan lingkungan dan sumber daya agar pembangunan berkelanjutan bagi generasi masa kini dan nanti dapat ditopang oleh keberadaan lingkungan dan sumberdaya yang lestari. Dalam hal ini pembangunan berkelanjutan yang berwawasan lingkungan berarti mengelola sumber daya untuk meningkatkan kesejahteraan generasi sekarang tanpa mengurangi kemampuan generasi masa akan datang untuk mengelola sumberdaya guna meningkatkan kesejahteraannya.

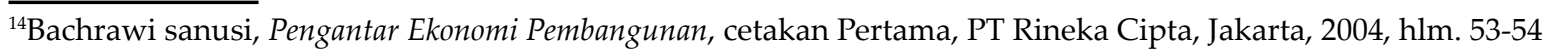

${ }^{15}$ A. Reni Widyastuti, Pengembangan Pariwisata yang Berorientasi Pada Pelestarian Fungsi Lingkungan, Jurnal Ekosains, Vol. II, No. 3, Oktober 2010.

${ }^{16}$ Guyer-Freuler dalam Nyoman S. Pendit dalam Darmawan Buamona, Pelaksanaan Kebijakan Pembangunan Kawasan Khusus Pariwisata di Kabupaten Kepulauan Sula Provinsi Maluku Utara Tahun 2014, Jurnal Ilmu Pemerintahan dan Kebijakan Publik, Vol. 2 No. 3, Okotober 2015.
} 


\section{METODE PENELITIAN}

Dalam penulisan ini menggunakan penelitian hukum normatif atau penelitian hukum doktrinal. Penelitian hukum normatif seperti ini biasa disebut penelitian hukum peraturan perundang-undangan. Penelitian hukum normatif ini mencakup penelitian terhadap asas-asas hukum, penelitian terhadap sistematika hukum, dan penelitian terhadap taraf sinkronisasi hukum.

Pendekatan yang digunakan dalam penulisan hukum adalah pendekatan perundangundangan (statute approach) dan pendekatan konsep (conceptual approach). Pendekatan perundangundangan adalah pendekatan yang dilakukan dengan menelaah semua undang-undang dan regulasi yang berkaitan dengan isu hukum yang ditangani. ${ }^{17}$

Teknik pengumpulan data menggunakan teknik studi kepustakaan yaitu dengan mengumpulkan, mempelajari dan menganalisa data yang diambil dari buku-buku atau pustaka, makalah, jurnal, artikel, surat kabar, dokumen-dokumen resmi yang diterbitkan maupun yang tidak diterbitkan, website serta media lain. Wawancara dilakukan terhadap narasumber untuk mengetahui lebih mendalam dan rinci, sehingga dengan adanya wawancara diharapkan dapat diperoleh data yang akurat tentang masalah yang diteliti.

\section{PEMBAHASAN}

\section{Potensi Wisata Kabupaten Gunungkidul}

Kabupaten Gunungkidul memiliki potensi wisata yang cukup potensial dan beragam, mulai dari kekayaan alam berupa pantai, goa, bukit dan pegunungan, tempat bersejarah serta desa wisata budaya maupun wisata religi. Kabupaten Gunungkidul juga memiliki wisata alam yang sangat unik berupa kawasan karst yang meliputi 10 wilayah kecamatan dengan luas $13.000 \mathrm{~km}^{2}$. Keunikan tersebut bercirikan fenomena di permukaan (ekokarst) dan bawah permukaan (endokarst). Beberapa tempat wisata di kawasan karst Kabupaten Gunungkidul yang banyak dikunjungi wisatawan antara lain: goa Ngingrong dan lembah Karst Mulo Kecamatan Wonosari, goa Jlamprong, goa Kali Suci, goa Jomblang dan goa Grubug Kecamatan Semanu, goa Seropan perbatasan Kecamatan Semanu dan Kecamatan Ponjong, goa Cokro Kecamatan Ponjong dan goa Pindul Kecamatan Karangmojo. ${ }^{18}$

Selain karena keindahannya, banyaknya pilihan rupanya juga menjadi alasan bagi wisatawan untuk berkunjung ke Kabupaten Gunungkidul. Jumlah wisata domestik (nasional) masih mendominasi kunjungan ke Kabupaten Gunungkidul dari pada wisatawan asing (manca negara). Berikut kami sajikan data jumlah kunjungan wisata Kabupaten Gunungkidul dari tahun 2013 sampai dengan tahun 2017.

Jumlah Kunjungan Wisatawan Kabupaten Gunungkidul Tahun 2013-2017'9

\begin{tabular}{cccccc}
\hline \multirow{2}{*}{ Wisatawan } & \multicolumn{5}{c}{ Tahun } \\
\cline { 2 - 6 } & 2013 & 2014 & 2015 & 2016 & 2017 \\
\hline Asing (Mancanegara) & 5.772 & 4.228 & 4.125 & 3.891 & 21.082 \\
Domestik (Nasional) & 1.766 .208 & 2.026 .026 & 2.638 .634 & 2.989 .006 & 3.236 .931 \\
Jumlah & $\mathbf{1 . 7 7 1 . 9 8 0}$ & $\mathbf{2 . 0 3 0 . 2 5 7}$ & $\mathbf{2 . 6 4 2 . 7 5 9}$ & $\mathbf{2 . 9 9 2 . 8 9 7}$ & $\mathbf{3 . 2 5 8 . 0 1 3}$ \\
\hline
\end{tabular}

Sumber : Dinas Pariwisata Kabupaten Gunungkidul, 2018

\footnotetext{
${ }_{17}$ Peter Mahmud Marzuki, Penelitian Hukum, Kencana Predana Media Group, Jakarta, 2011, hlm. 24 ${ }^{18}$ BAPPEDA Kabupaten Gunungkidul, Informasi Pembangunan Kabupaten Gunungkidul Tahun 2018, hlm 37. ${ }^{19}$ Ibid.
} 


\section{Kerusakan Lingkungan di Kawasan Wisata Kabupaten Gunungkidul}

Pariwisata adalah industri yang kelangsungan hidupnya sangat ditentukan oleh baik buruknya lingkungan. Sektor wisata sebagai industri jasa merupakan sektor yang sangat peka terhadap lingkungan. Kerusakan lingkungan seperti pencemaran limbah domestik, kumuh, adanya gangguan terhadap wisatawan, penduduk yang kurang/tidak bersahabat, kesemerautan lalulintas, kriminalitas, dan lain-lain, akan dapat mengurangi jumlah wisatawan yang berkunjung ke suatu daerah tujuan wisata. Oleh karena itu pengembangan pariwisata harus menjaga kualitas lingkungan. ${ }^{20}$

Berdasarkan Undang-Undang Nomor 10 Tahun 2009 tentang Kepariwisataan, Pasal 4 huruf e disebutkan bahwa kepariwisatan bertujuan untuk melestarikan alam, lingkungan dan sumber daya. Sehingga apabila pengelolaan pariwisata menimbulkan dampak kerusakan lingkungan hal tersebut bertentangan dengan tujuan diselenggarakannya pariwisata.

Banyak dijumpai kerusakan lingkungan akibat dibangunkan suatu kawasan menjadi kawasan wisata antara lain:

1. Kawasan Wisata Goa Pindul

Pembangunan pariwisata di Goa Pindul yang terletak di desa Bejiharjo Kecamatan Karangmojo Kabupaten Gunungkidul. Akses yang semakin mudah sebagai akibat adanya pembangungan sarana dan prasarana berujung pada semakin banyaknya wisatawan yang berkunjung ke objek wisata ini. Hal ini berdampak positif karena mampu meningkatkan kondisi ekonomi masyarakat yang bermukim disekitar kawasan objek wisata. Namun, apabila pembangunan kawasan objek wisata ini hanya menekankan pada dampak ekonomi tanpa memperhatikan kondisi lingkungan saja maka kelestariannya akan terancam. Pengunjung yang membanjiri Goa Pindul tanpa memperhatikan kapasitas tampung maupun daya dukung lingkungan hendaknya diperhatikan agar keberlanjutan (sustainability) objek wisata ini tetap terjaga.

Jumlah wisatawan yang melebihi daya dukung "carrying capacity" Goa Pindul atau overload mengakibatkan timbulnya berbagai masalah ekosentrisme terhadap alamnya. Hal ini bertentangan dengan status objek wisata Goa Pindul yang berbasis ekowisata dengan menekankan pada penerapan wawasan lingkungan menggunakan aspek konservasi alam. Berbagai masalah ekosentrisme yang dapat terjadi apabila overload ini terus terjadi antara lain $^{21}$ :

a. Masalah Air dan Rusaknya Siklus Kehidupan Goa

b. Rusaknya Ornamen-Ornamen Goa

2. Pantai Seruni

Kerusakan lingkungan di kawasan wisata juga terjadi di Pantai Seruni yang berada di wilayah desa Tepus Kecamatan Tepus Kabupaten Gunungkidul. Pantai Seruni sekarang sedang dibangun proyek hotel dan resor bernama South Mountain Paradise. Proyek ini milik P.T. Gunung Samudera Tirtomas dengan bos Robinson Saalino.Ia merupakan direktur utama pada perusahaan yang bergerak dalam jasa konstruksi, properti dan pariwisata ini. Dalam master plan, Gunung Samudera Tirtomas akan membangun hotel dengan konsep tiga gedung dengan kolam renang utama di tengah, dikelilingi resor menghadap pantai.

\footnotetext{
${ }^{20} \mathrm{http} / / /$ jembatan4.blogspot.com/2013/10/pariwisata-dan-masalah-lingkungan.html, diunduh tanggal 11 April 2019, pukul 11.27 WIB.

${ }^{21}$ https://dokumen.tips/download/link/masalah-lingkungankawasan-wisata-goa-pindul, diunduh tanggal 10 April 2019, pukul 01.30 WIB.
} 
Lembah karst ini sedang disulap menjadi bangunan megah mirip Atlantis Beach Tower Hotel di Paradise Island, Bahama. Proyek ini menempati lahan seluas 76 hektare. Maket, dan denah lokasi telah terpampang di Pantai Seruni.

Menurut Direktur Eksekutif Walhi Yogyakarta Halik Sandera, Pantai Seruni berada di kawasan bentang alam karst Gunungsewu, suatu kawasan lindung geologi yang merupakan bagian dari kawasan lindung nasional. Proyek South Mountain Paradise, kata dia, berdiri di kawasan lindung, dan merusak lingkungan. “UNESCO dan Pemerintah Republik Indonesia telah menetapkannya sebagai kawasan lindung geologi yang wajib dilestarikan demi keseimbangan alam dan pengembangan ilmu pengetahuan," katanya. ${ }^{22}$

Ada dua peraturan yang dilanggar dalam pembangunan hotel tersebut yang pertama pelanggaran terhadap Undang-Undang Nomor 10 Tahun 2009 tentang Kepariwisataan dan Undang-Undang Nomor 26 tahun 2017 tentang Tata Ruang. Namun demikian belum ada tindakan tegas dari Pemerintah untuk menghentikan pembangunan tersebut dengan dalih bahwa hotel tersebut di bangun di atas tanah Sultan Ground dan telah mendapatkan kekancingan dari Keraton Yogyakarta.

\section{Gunung Api Purba Nglanggeran}

Ditempat lain kerusakan lingkungan di kawasan wisata berbeda lagi seperti di desa wisata Gunung Api Purba di Kecamatan Patuk Kabupaten Gunungkidul, kegiatan pariwisata di Desa Nglanggeran tersebut, jika kita amati secara umum situasi dan kondisi lingkungan hidup di kawasan pariwisata Desa Nglanggeran tampak baik, lingkungannya asri, dan terlihat bersih. Apalagi, Pokdarwis Nglanggeran menggunakan label "ekowisata" dalam mengelola bisnis pariwisata di desa tersebut.

Namun demikian, jika diperdalam melalui pencermatan pendekatan diskriptif kualitatif, analisis data dengan menggunakan teori dan perspektif, penelitian ini ${ }^{23}$ telah menemukan beberapa kerusakan lingkungan, baik terkait aspek abiotik, biotik, maupun aspek sosial dan budaya. Temuan tentang kerusakan lingkungan tersebut dapat disederhanakan dalam tiga poin utama berikut ini.

Pertama, telah terjadi kerusakan lingkungan fisik, sekalipun masih tergolong sedang, di beberapa tempat di kawasan obyek wisata di Desa Nglanggeran, diantaranya di jalur pendakian di situs gunung api purba dan di sekitar embung buatan, termasuk di bagian jalan tembus baru.

Kedua, terjadi kerusakan lingkungan biotik, juga tergolong sedang,di beberapa lokasi di kawasan obyek wisata di Desa Nglanggeran. Kerusakan itu, terutama pada hilangnya vegetasi dan terganggunya ruang hidup organisme di jalur pendakian dan di sekitar embung buatan.

\section{Upaya Pemerintah Kabupaten Gunungkidul Dalam Mewujudkan Dan Meningkatkan Pembangunan Pariwisata Yang Berwawasan Lingkungan.}

Dalam rangka mewujudkan dan meningkatkan pembangunan pariwisata di Kabupaten Gunungkidul dengan tetap menjaga lingkungan dan kelestarian alam telah ditempuh kebijakankebijakan sebagai berikut :

\footnotetext{
${ }^{22} \mathrm{https} / /$ investigasi.tempo.co/karst-yogyakarta/index.html, diunduh tanggal 10 april 2019, pukul 01.45 WIB.

${ }^{23}$ Sugeng Yulianto, 2016 “Kajian Kerusakan Lingkungan Akibat Kegiatan Pariwisata Di Desa Ngalanggeran, Kecamatan Patuk, Kabupaten Gunungkidul, Propinsi Daerah Istimewa Yogyakarta” (Tesis tidak diterbitkan, Pascasarjana Universitas Gajah Mada), hal 161-162.
} 
1. Memasang Papan Rambu Lingkungan Hidup di tempat-tempat wisata. ${ }^{24}$ Dinas Lingkungan Hidup Kabupaten Gunungkidul melakukan kegiatan memasang Papan Rambu Lingkungan Hidup. Kepala Bidang Konservasi dan Kerusakan Lahan Dinas Lingkungan Hidup Kabupaten Gunungkidul menyampaikan data obyek wisata yang dipasang Papan Rambu Lingkungan Hidup.

Keberadaan rambu-rambu lingkungan hidup tidak sepopuler rambu-rambu lalu lintas yang setiap orang hampir mengetahuinya. Rambu-rambu lalu lintas telah diatur secara lengkap dengan mendasarkan pada Peraturan Menteri Perhubungan Nomor PM 13 Tahun 2014 tentang Rambu Lalu Lintas. Berbeda dengan rambu lingkungan hidup, belum ada peraturan secara pasti yang mengatur tentang rambu-rambu lingkungan hidup. Kepala Bidang Konservasi dan Kerusakan Lahan Dinas Lingkungan Hidup Kabupaten Gunungkidul ketika penulis hubungi terkait dengan peraturan yang menjadi dasar pembuatan rambu-rambu lingkungan hidup belum bisa memberi jawaban. Namun demikian keberadaan rambu-rambu lingkungan hidup tetap sebagai hukum yang berlaku dalam masyarakat. Rambu-rambu lingkungan hidup memberi manfaat bagi masyarakat agar senantiasa memperhatikan masalah lingkungan hidup. Hal tersebut senada dengan Prinsip aliran Utilitarianisme ini adalah bahwa masyarakat bertindak untuk memperbanyak kebahagiaan dan mengurangi penderitaan. Sebagaimana yang diungkapkan oleh Jeremy Bentham (1748-1832) yaitu:

"Dalam teorinya tentang hukum, Bentham menggunakan salah satu prinsip dari aliran utilitarianisme yakni bahwa manusia bertindak untuk memperbanyak kebahagiaan dan mengurangi penderitaan... setiap kejahatan harus disertai dengan hukuman-hukuman yang sesuai dengan kejahatan tersebut. Dan hendaknya penderitaan yang dijatuhkan tidak lebih dari apa yang diperlakukan untuk mencegah terjadinya kejahatan".

Jeremy Bentham (1748-1832) Berpendapat: Bahwa alam memberikan kebahagiaan dan kerusakan. Tugas Hukum adalah memelihara kebahagiaan dan mencegah kejahatan. Menurutnya pemidanaan haruslah bersifat spesifik untuk tiap jenis kejahatan, dan seberapa besar pidana itu boleh diberikan, hal ini tidak boleh melebihi jumlah yang dibutuhkan untuk mencegah timbulnya kejahatan. ${ }^{25}$

2. Menempatkan petugas kebersihan di obyek-obyek wisata.

Kepala Subbagian Tata Usaha UPT Kebersihan dan Pertamanan Dinas Lingkungan Hidup Kabupaten Gunungkidul menyampaikan bahwa untuk menjaga kebersihan dan kenyamanan pengunjung wisata, Dinas Lingkungan hidup menempatkan petugas kebersihan di lokasi-lokasi wisata sebanyak 36 (tiga puluh enam) orang yang terdiri dari 2 orang Pegawai Negeri Sipil dan sebanyak 34 (tiga puluh empat) orang berstatus sebagai Tenaga Harian Lepas (THL) ${ }^{26}$. Kesemuanya bertugas di pantai untuk memelihari kebersihan pantai. Selain di tempat-tempat wisata, Dinas Lingkungan Hidup juga menempatkan petugas-petugas kebersihan di tempat penunjang pariwisata taman perbatasan sebanyak 5 (lima) orang

\footnotetext{
${ }^{24}$ Ir. Luh Gde Suastini, Kepala Bidang Konservasi dan Kerusakan Lahan Dinas Lingkungan Hidup Kabupaten Gunungkidul, dalam wawancara dengan Penulis melalui Whats App, 20 Februari 2019, Izin mengutip telah diberikan.

${ }^{25}$ M.Chairul Basrun Umanailo, 2016, Sosiologi Hukum, FAM PUBL SING, hlm 49-50

${ }^{26}$ Riyanto., Kepala Subbagian Tata Usaha UPT Kebersihan dan Pertamanan Dinas Lingkungan Hidup Kabupaten Gunungkidul, Dalam wawancara dengan Penulis melalui Whats App, 15 Februari 2019, Izin mengutip telah diberikan.
} 
Tenaga Harian Lepas yaitu di Taman Perbatasan Patuk petugas kebersihan dilakukan oleh Tenaga Harian Lepas sebanyak 3 (tiga) orang, Taman Perbatasan Ngawen petugas kebersihan dilakukan oleh Tenaga Harian Lepas sebanyak 1 (satu) orang dan Taman Perbatasan Semin petugas kebersihan dilakukan oleh Tenaga Harian Lepas sebanyak 1 (satu) orang. Tugas utamanya adalah memelihara taman dan menjaga kebersihan Taman Perbatasan.

\section{Ekowisata atau Ekotorisme}

Menurut Kepala Sub Bagian Perencanaan Sekretariat Dinas Kepariwisataan Kabupaten Gunungkidul,ekowisata atau ekotorisme merupakan pemberdayaan masyarakat kawasan daya tarik wisata dengan pengembangan usaha pariwisata sebagai pendukung utama suatu destinasi wisata ${ }^{27}$. Contoh destinasi wisata Nglanggeran. Dengan menggali potensi yang ada dikawasan tersebut seperti pengembangan coklat, homestay, pramuwisata atau pemandu dan lain-lain. Sehingga wisatawan selain menikmati daya tarik wisata Gunung Apri Purba dan Embung Nglanggeran dapat menikmati daya tarik lainnya yaitu kuliner, penginapan dan lain-lain.

Sedangkan ekowisata atau ekoturisme ${ }^{28}$ merupakan salah satu kegiatan pariwisata yang berwawasan lingkungan dengan mengutamakan aspek konservasi alam, aspek pemberdayaan sosial budaya ekonomi masyarakat lokal serta aspek pembelajaran dan pendidikan. Ekowisata dimulai ketika dirasakan adanya dampak negatif pada kegiatan pariwisata konvensional. Dampak negatif ini bukan hanya dikemukakan dan dibuktikan oleh para ahli lingkungan tetapi juga para budayawan, tokoh masyarakat dan pelaku bisnis pariwisata itu sendiri. Dampak berupa kerusakan lingkungan, terpengaruhnya budaya lokal secara tidak terkontrol, berkurangnya peran masyarakat setempat dan persaingan bisnis yang mulai mengancam lingkungan, budaya dan ekonomi masyarakat setempat.Pada mulanya ekowisata dijalankan dengan cara membawa wisatawan ke objek wisata alam yang eksotis dengan cara ramah lingkungan. Proses kunjungan yang sebelumnya memanjakan wisatawan namun memberikan dampak negatif kepada lingkungan mulai dikurangi.

\section{Penyusunan AMDAL Kawasan Pariwisata}

Analisis Mengenai Dampak Lingkungan (AMDAL) kawasan pariwisata merupakan hal yang sangat penting untuk meminimalisir kerusakan lingkungan yang ditimbulkan dari kegiatan pariwisata sehingga dari awal sudah ada perencanaan pengelolaan dan evaluasi kegiatan disuatu kawasan pariwisata, sehingga kelestariannya tetap terjaga.

Analisis dampak lingkungan ${ }^{29}$ (bahasa Inggris:Environmental impact assessment) atau Analisis mengenai dampak lingkungan (di Indonesia, dikenal dengan nama AMDAL) adalah kajian mengenai dampak besar dan penting suatu usaha dan/atau kegiatan yang direncanakan pada lingkungan hidup yang diperlukan bagi proses pengambilan keputusan tentang penyelenggaraan usaha dan/atau kegiatan di Indonesia. AMDAL ini dibuat saat perencanaan suatu proyek yang diperkirakan akan memberikan pengaruh terhadap lingkungan hidup

\footnotetext{
${ }^{27}$ Supriyanto, S.Sos, MM, Kepala Sub Bagian Perencanaan Sekretariat Dinas Kepariwisataan Kabupaten Gunungkidul, Dalam wawancara dengan Penulis melalui Whats App, 10 Februari 2019, Izin mengutip telah diberikan.

${ }^{28} \mathrm{https}$ ///id.wikipedia.org/wiki/Ekowisata, diunduh tanggal 26 Maret 2019 jam 07.52 WIB.

${ }^{29}$ https://id.wikipedia.org/wiki/Analisis_dampak_lingkungan, diunduh tanggal 26 Maret 2019, pukul 08.59.
} 
disekitarnya. Yang dimaksud lingkungan hidup di sini adalah aspek abiotik, biotik dan kultural. Dasar hukum AMDAL di Indonesia adalah Peraturan Pemerintah Nomor 27 Tahun 2012 tentang "Izin Lingkungan Hidup" yang merupakan pengganti Peraturan Pemerintah Nomor 27 Tahun 1999 tentang Amdal. Amdal telah dilaksanakan sejak 1982 di Indonesia.

Kepala Bidang Pengembangan dan Destinasi Dinas Pariwisata Gunungkidul menambahkan bahwa nanti arahnya semua destinasi akan dilakukan AMDAL/UKL-UPL. ${ }^{30}$ Contoh tempat wisata yang sudah dilakukan amdal kawasan wisata adalah Desa Bejiharjo Kecamatan Karangmojo termasuk didalamnya Kawasan Wisata Goa Pindul. Untuk Tahun 2019 akan disusun amdal untuk kawasan wisata Desa Bleberan atau di Air Terjun Sri Getuk. Untuk kawasan wisata Goa Kali Suci akan di lakukan UKL-UPL. Untuk kawasan wisata Gunung Api Purba Nglanggeran Desa Patuk belum dilakukan amdal tetapi sudah menerapkan suistenable tourism.

Pedoman Penyusunan amdal, UKL-UPL, SPPL di atur dalam Peraturan Menteri Negara Lingkungan Hidup Republik Indonesia Nomor 16 Tahun 2012 tentang Pedoman Penyusunan Dokumen Lingkungan Hidup.

Kalau dikaitkan dengan kebijakan pembangunan pariwisata di Kabupaten Gunungkidul bahwa penyusunan amdal dan UKL-UPL baru dilaksanakan pada beberapa tempat wisata tentu hal tersebut bertentangan dengan Peraturan Menteri Negara Lingkungan Hidup Republik Indonesia Nomor 16 Tahun 2012 tentang Pedoman Penyusunan Dokumen Lingkungan Hidup, karena seharusnya penyusunan amdal dan UKL-UPL dilaksanakan sebelum adanya kegiatan pariwisata.

5. Pengelolaan Daya Tampung dan Daya Dukung Daya Tarik Wisata.

Kondisi suatu Daya Tampung Wisata menjadi dasar pertimbangan dalam penerimaan kunjungan wisatawan sehingga antara penyelenggara dan pelaku wisata dapat menikmati Daya Tarik Wisata. Contoh beberapa waktu yang lalu di destinasi wisata Goa Pindul karena tidak dibatasi pengunjungnya pernah viral seperti cendol saat antri masuk. Sehingga menimbulkan kesan yang tidak baik bagi semua pelaku usaha pariwisata. Selain itu juga harus memperhatikan keamanan, jam kunjung dan lain-lain. Sehingga penyelenggara dan pelaku wisata dapat bersinergi dalam pengelolaan destinasi wisata. Pengunjung tidak merasa dirugikan demikian juga penyelenggara dapat memberikan pelayanan yang sebaik-baiknya. ${ }^{31}$

\section{PENUTUP}

Kerusakan lingkungan di kawasan wisata di Kabupaten Gunungkidul telah terjadi antara lain: di kawasan wisata Goa Pindul yang terletak di Desa Bejiharjo Kecamatan Karangmojo, kawasan wisata pantai Seruni yang terletak di Desa Tepus Kecamatan Tepus dan Kawasan Wisata Gunung Api Purba Nglanggeran yang terletak di Desa Nglanggeran Kecamatan Patuk karena kesalahan dalam pengelolaannya. Walaupun kerusakan yang terjadi masih dapat dikategorikan kerusakan ringan namun demikian perlu dilakukan langkah-langkah penghentian dan pencegahan kerusakan.

\footnotetext{
${ }^{30}$ Supartono,ST,MT, Kepala Bidang Pengembangan dan Destinasi Dinas Pariwisata Gunungkidul, Dalam wawancara dengan Penulis melalui Whats App, 10 Februari 2019, Izin mengutip telah diberikan.

${ }^{31}$ Supriyanto, S.Sos, MM, Kepala Sub Bagian Perencanaan Sekretariat Dinas Kepariwisataan Kabupaten Gunungkidul, Loc. Cit.
} 
Potensi dan obyek-obyek wisata harus tetap dijaga kelestariannya untuk masa depan generasi yang akan datang. Jangan sampai dengan alasan untuk meningkatkan perekonomian masyarakat dan meningkatkan untuk Pendapatan Asli Daerah bagi Pemerintah mengesampingkan atau mengabaikan kelestarian alam di obyek wisata. Karena hal tersebut sangat bertentangan dengan Undang-Undang Nomor 10 Tahun 2009 tentang Kepariwisataan, Pasal 4 huruf e yang disebutkan bahwa kepariwisataan bertujuan untuk melestarikan alam, lingkungan dan sumber daya. Sehingga apabila pengelolaan pariwisata menimbulkan dampak kerusakan lingkungan hal tersebut bertentangan dengan tujuan diselenggarakannya pariwisata.

Untuk melaksanakan amanat Undang-Undang Nomor 10 Tahun 2009 tentang Kepariwisataan, Pemerintah Kabupaten Gunungkidul telah melakukan kebijakan pembangunan pariwisata yang berwawasan lingkungan dengan mengambil langkah-langkah sebagai berikut :

1. Menetapkan Peraturan Daerah Kabupaten Gunungkidul Nomor 5 Tahun 2013 tentang Penyelenggaraan Kepariwisataan;

2. Menetapkan Peraturan Daerah Nomor 3 Tahun 2014 tentang Rencana Induk Pembangunan Kepariwisataan Derah Kabupaten Gunungkidul Tahun 2014-2025 ;

3. Memasang Papan Rambu Lingkungan Hidup di tempat-tempat wisata;

4. Menempatkan petugas kebersihan di obyek-obyek wisata;

5. Ekowisata atau Ekotorisme;

6. Penyusunan AMDAL Kawasan Pariwisata;

7. Pengelolaan Daya Tampung dan Daya Dukung Daya Tarik Wisata.

\section{DAFTAR PUSTAKA}

Ir. Luh Gde Suastini, Kepala Bidang Konservasi dan Kerusakan Lahan Dinas Lingkungan Hidup Kabupaten Gunungkidul, dalam wawancara dengan Penulis melalui Whats App, 20 Februari 2019, Izin mengutip telah diberikan.

M.Chairul Basrun Umanailo, 2016, Sosiologi Hukum, FAM PUBL SING

Peter Mahmud Marzuki, Penelitian Hukum, Kencana Predana Media Group, Jakarta, 2011.

R.I., Undang-Undang Dasar 1945, Bab XIV

R.I., Undang-Undang Nomor 10 Tahun 2009 tentang Kepariwisataan

R.I., Undang-UndangNomor 32 Tahun 2009 tentang Perlindungan dan Pengelolaan Lingkungan Hidup Riyanto., Kepala Subbagian Tata Usaha UPT Kebersihan dan Pertamanan Dinas Lingkungan Hidup Kabupaten Gunungkidul, Dalam wawancara dengan Penulis melalui Whats App, 15 Februari 2019, Izin mengutip telah diberikan.

Sugeng Yulianto, 2016 “Kajian Kerusakan Lingkungan Akibat Kegiatan Pariwisata Di Desa Ngalanggeran, Kecamatan Patuk, Kabupaten Gunungkidul, Propinsi Daerah Istimewa Yogyakarta" (Tesis tidak diterbitkan, Pascasarjana Universitas Gajah Mada), hal 161-162.

Supartono,ST,MT, Kepala Bidang Pengembangan dan Destinasi Dinas Pariwisata Gunungkidul, Dalam wawancara dengan Penulis melalui Whats App, 10 Februari 2019, Izin mengutip telah diberikan.

Supriyanto, S.Sos, MM, Kepala Sub Bagian Perencanaan Sekretariat Dinas Kepariwisataan Kabupaten Gunungkidul, Dalam wawancara dengan Penulis melalui Whats App, 10 Februari 2019, Izin mengutip telah diberikan. 
Timang Setyorini, SH, 2004,"Kebijakan Pariwisata Dalam Rangka Meningkatkan Pendapatan Ekonomi Masyarakat Kabupaten Semarang" (Tesis Pascasarjana tidak diterbitkan, Program Magister Ilmu Hukum Universitas Diponegoro Semarang)

BAPPEDA Kabupaten Gunungkidul, Informasi Pembangunan Kabupaten Gunungkidul Tahun 2018. https://borneotourismwatch.wordpress.com/2009/09/09/pariwisata-alternatif-apa-itu, diunduh tanggal 30 Oktober 2018, pukul 09.45 WIB.

https://dokumen.tips/download/link/masalah-lingkungankawasan-wisata-goa-pindul, diunduh tanggal 10 April 2019, pukul 01.30 WIB.

http:/gunungkidulkab.go.id/D-947db8881fd2f1e605a1fe29a8b6aa6c-NR-100-0.html, diunduh pada tanggal 22 Juni 2018, pukul 08.30.

https://investigasi.tempo.co/karst-yogyakarta/index.html, diunduh tanggal 10 april 2019, pukul 01.45 WIB.

https://id.wikipedia.org/wiki/Analisis_dampak_lingkungan, diunduh tanggal 26 Maret 2019, pukul 08.59.

https://id.wikipedia.org/wiki/Ekowisata, diunduh tanggal 26 Maret 2019 jam 07.52 WIB.

http://jembatan4.blogspot.com/2013/10/pariwisata-dan-masalah-lingkungan.html, diunduh tanggal 11 April 2019, pukul 11.27 WIB.

http://wisata.gunungkidulkab.go.id/, diunduh pada tanggal 22 Juni 2018, pukul 09.30. 